\title{
KOMI FOLKLORE. COLLECTED BY PAUL ARISTE
}

\section{Nikolai Kuznetsov}

\begin{abstract}
Academician Paul Ariste's collection of Komi folklore have been recorded from male informants in 1941 and 1942 in Tartu. The ethnic Komi informants resided in Tartu as prisoners of war. The original texts have been written in transcription and each text is followed by a translation into Estonian. The materials represent a wide range of genres, including Komi chastushkas, folk songs, riddles, jokes, legends, folk tales, etc. Beside of this were is a collection of the Komi material from Aleksei Rakov: it includes abundant information about the ethnography, Rakov has illustrated the text with numerous drawings, which is an important and informative addition to the ethnographic descriptions. The texts have been written down in the so-called Molodtsov alphabet, the alphabet was used in the Komi area during 1918-1932 and during 1934-1936.
\end{abstract}

Keywords: Paul Ariste, ethnogrphy, Komi, folklore.

Interestingly, Paul Ariste's collection of Komi folklore never took him to the Komi area. Regardless of that, his material collected from the Komi are held together with the manuscript files of other Finno-Ugric peoples in the Estonian Folklore Archives of the Estonian Literary Museum (EKM ERA) (see RKM, Soomeugri 2, 73/316; RKM, Soome-ugri 3, 9/256; RKM, Soome-ugri 9, 1/ 169 and RKM, Mitmesugused rahvad, 45/88). The collected Komi materials have been recorded from male informants in 1941 and 1942 in Tartu. The ethnic Komi informants resided in Tartu as prisoners of war. Some young men came from the Komi-Permyak Autonomous District, other informants had come from different dialectal areas of the then Komi Autonomous Soviet Socialist Republic (A.S.S.R.). Among Ariste's informants was a Russian, on whom Ariste comments that he "...has attended a Zyrian school. His wife is Komi-Zyrian. He has a slight Russian accent." (Komi Folklore 2005: 19). This young man has contributed a single lengthier text. The number of recordings from specific informants also varies.

The file RKM, Soome-ugri 2 consists of 244 pages of folkloric material collected from the Komi and recorded by Paul Ariste himself. The original texts have been written in transcription and each text is followed by a translation into Estonian. A good 
example here is a Komi-Permyak riddle recorded from Afonassei Samkov:

vunda.la, vunda.la, vires abu, muna, muna, tui abu? - piž. I'm cutting, cutting, no blood, I am going, going, no road. - A boat. (Komi Folklore 2005: 35)

The fact that no translation has been provided for the last text (Komi Folklore 2005: 34) indicates that the files are incomplete. Even though the last text is numbered 223, the total number of entries is 219 , as texts numbers $141,142,143$ and 144 are missing in the original manuscript. Each text (in some cases several texts) is followed by the place and time of collection and information about the performer, including his name and, at the first mention of the informant, also additional personal information. Even though information about the performer has not been added to the last ten texts, the file $R K M, V E X X I V$ (see further on this issue below) presents some of the ten texts together with the performer's name; thus, considering their similarity in dialectal idiosyncrasies we have reason to believe that the last texts of the file RKM, Soome-ugri 2 have been recorded from the same informant.

The materials of the file RKM, Soome-ugri 2 represent a wide range of genres, including Komi chastushkas, folk songs, riddles, jokes, legends, folk tales, etc. Since the performers have come from different dialectal areas, the language of the texts differs considerably. The texts included in this publication are in KomiPermyak and Komi-Zyrian varieties. Here are some examples:

t'šuži bidmi śed_ver šere ( šerra), d'erévíáe peti.

nolli $t$ 'śored sera derem.

vižža gat'š́da keti.

i murtsa suvti as kokjile,

$i$ udžper menem vit'śmis:

zipka dorin evve síwni,

it'šset kaga vid'źni.

me l'ul'àla it'šet kaga:

l'ul'ibai da l'ul'i bai.
I was born and grew up in a black forest,

Went to the village.

I was wearing a stiff grey shirt,

Striped trousers and clogs.

As soon as I got to my feet,

And there was work for me:

Singing oo-oo by the cradle,

Babysitting a small kid.

I sing lullabies to the small kid:

l'ul'i bai and l'ul'i bai

(Komi Folklore 2005: 35) 
suśe tku suśe tko. jeśli kin t'śoža kulas, to sija odpik adpi.las suśe tkoleś pet'śke.m. - mam viśta las zonkale: en pir t'śasit dpodpi.las suśe tku śojas. suśe tkose šueni. sija pe e d'd'en ut't'śiki k, da kuźjurśi.ja. nilka loas ńeve-sta. sija oinas veta-śas. - talun pe oinas menem suśe tho davi.tlis. a silen dugdi.llis ud'źa.lni vir.

S[us'etku sus'etko] (revenant or домоводец in Russian). When a person is about to die, he or she sees the s[us'etku]. Mother tells her son: Don't go to the larder behind the stove. S[us'etku] will eat you. They told about s[us'etko] that it is quite small, and has long hair. The girl will be the bride. He dreams about it at night. The s[us'etko] haunted me tonight. But his blood stopped working. (Komi Folklore 2005: 54-57)

тедла реліп utka gorze, kenke kiлe keke kek;

menam musuk kiле лоkte, vorsigterje gudeken.

(Komi Folklore 2005: 64, 65)
On the other side of the river a duck is quacking,

A cuckoo is heard cuckooing somewhere;

My darling is heard coming, Playing the concertina.

\section{l'on ńetška: $\underline{n}$ kad.}

l'on netškini ponde ·t'śäni awgusta meśätsлin. l'on ed'd'än bura kuźa bidmis. t'sel'àd' t'śukert't'sisä l'on mu? ä, i ponde ‘t'śisä l'on netškini, l'on kedija pondis kerni vetša'aez kośtini l'on. kośte $m$ berśán ponde t'śisä l'on jur vart? ini. med bur l'on pondisä berin i gosudárstvo ä sit'e'ts kerni $i$ nańka kerni i $i$ t'set'śkom jerne sez ${ }^{2} \ddot{g}$. ed'd'än bura kerä mijän l'oniś novjan paśkämm.

\section{Time to harvest flax}

Flax is picked in August. Flax grew very long. Children gather on the flax field and start picking flax. Some people started to make a scaffold for setting the flax up to dry. After drying flax is swingled. The best flax is picked for calico and white linen. Very good clothes are made of our flax.(Komi Folklore 2005: 200, 201)

Paul Ariste managed to publish some texts included in this publication (see Ariste 1976: 92-115; 1978: 81-99; 1980: 25-29; 1990: 156-163). In the Fenno-Ugristica series he has published in the Komi-Zyrian language 11 texts recorded from Kirill Ulyashev, eight texts from Kirill Zhizhov, three texts from Pavel Kustyshev, and seven texts in Komi-Permyak from Nikolai Isaev from the 
Komi Autonomous Area. The texts in Fenno-Ugristica are published with German translations. The rest of the materials had not been published until recently. The structure of this manuscript, which was completed in 1943, follows that of a book, including a table of contents and a brief foreword in German. All texts are numbered and translated into German.

The Komi material included in the file RKM, Soome-ugri 3 has been recorded from one person. On October 16, 1960 Ariste writes about Aleksei Rakov, the informant and performer of texts in this file:

Komi folklore and ethnographical materials have been recorded by Aleksei Rakov, who comes from Komi ASSR Syktyvdin District, Yb village community, Jol village

The records were made in Tartu. Aleksei Rakov had become a war prisoner and was sent to work in AKS. I studied the Komi language from him. The young man had secondary education. Later he was sent to a camp in Latvia, where he probably perished.

Enclosed is a letter in Komi and another in Russian about his life. The collected material is extremely valuable (RKM, Soome-ugri 3, 231).

While writing these words, Ariste was not aware of the actual fate of his former informant. Aleksei Rakov wrote to Ariste tens of years later from the Komi area. Two of his letters, written in 1988, are held in the Estonian Cultural History Archives of the Estonian Literary Museum (EKLA, f 330, m 78:10). Rakov writes that he has arrived safely home from imprisonment, describes his life and expresses his gratitude to Ariste for his kindness. Next to these letters the Estonian Cultural History Archives also includes Ariste's draft manuscripts containing material collected from the Komi prisoners of war (EKLA, f 330, m 233:2) and comments to texts by A. Rakov (EKLA, f 330, m 167:13). The first notebook includes descriptions of some characteristics of the Komi grammar,

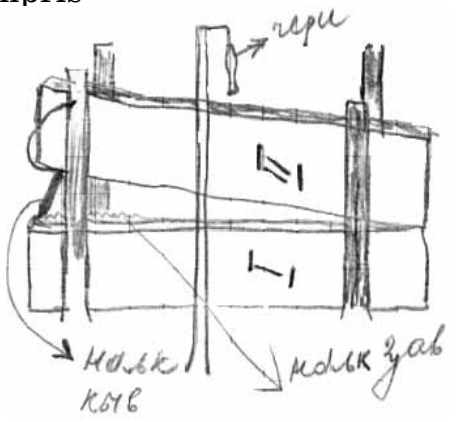

Figure 1. Trap (RKM, Soomeugri 3,43$)$ 


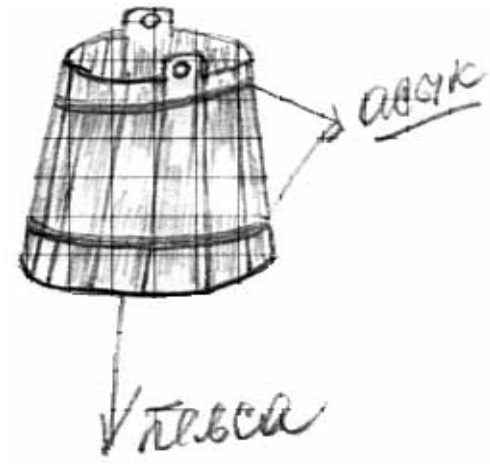

Figure 2. Tub (RKM, Soomeugri, 3, 104)

glossary of Komi words, translations and comments to some recorded texts. The second notebook includes comments on Rakov's language use (and that of some other Zyrians) based on his texts.

The material collected from Rakov is indeed valuable - firstly, because it includes abundant information about the life of the Komi in the past. Material on ethnography is very copious. The informant has described various forms of hunting and hunting gear, methods of fishing and fishing gear, the tools and commodities used in farming, hay-making and household chores, structure of house and transport vehicles, clothing and cooking, various types of work, children's games, etc.

Secondly, Rakov has illustrated the text with numerous drawings, which is an important and informative addition to the ethnographic descriptions. The illustrations are drawn in great detail and are very accurate.

Thirdly, the texts have been written down in the so-called Molodtsov alphabet, making thus an intriguing topic of study. The alphabet was used in the Komi area during 1918-1932 and during 1934-1936 around which time Aleksei Rakov must have attended school. This probably explains his use of the alphabet which had become obsolete by 1941 .

The file RKM, Mitmesugused rahvad contains relatively little material on the Komi folklore. Most of the texts cannot even be considered authentically folkloric or ethnographic, as they are mainly descriptions of the informant's personal life. Some texts, however, are analogous to bylichkas or folk tales. One text (on page 83/7) includes a text which is also included in the above files, and another text (on page 47/8) is a fragment of a joke recorded by A. Rakov. 
The described archival materials will definitely be of interest to folklorists and ethnographers, as well as to linguists, dialectologists and everyone else interested in the Komi language and culture, and definitely deserves further investigation.

\section{Archival sources:}

\section{Estonian Folklore Archives}

RKM, Soome-ugri $=$ Folklore files of the Department of Folkloristics of the former F. R. Kreutzwald's (National) Literary Museum of the Estonin Academy of Sciences (now Estonian Literary Museum), consisting of 445,780 pages (collected mostly since 1945), according to the statistics in January 1995.

Estonian Cultural History Archives

EKLA, f 330: Ariste (Berg), Paul (1905-1990) - linguist, folklorist, 3,366 archive items (1772-1995).

\section{Reference:}

Ariste, Paul 1976. Komi-Syrjänisches aus Puzla. Palmeos, Paula et al. (toim). Fenno-Ugristica 2 = Труды по финно-угроведению. Tartu Riikliku Ülikooli toimetised = Ученые записки Тартуского государственного университета = Acta et commentationes Universitatis Tartuensis 382. Tartu: [Tartu Riiklik Ülikool], lk 92-115.

Ariste, Paul 1978. Komi-Permisches aus Gaincovo. Künnap, Ago \& Palmeos, Paula (toim). Fenno-Ugristica 5: Uurali keelte grammatiline ehitus = Труды по финно-угроведению 5: Грамматический строй уральских языков. Tartu Riikliku Ülikooli toimetised = Ученые записки Тартуского государственного университета = Acta et commentationes Universitatis Tartuensis 456. Tartu: [Tartu Riiklik Ülikool], lk 81-99.

Ariste, Paul 1980. Komi-Syrjänisches aus dem Dorfe Nivšera. Fennougristica 7 = Труды по финно-угроведению. Tartu Riikliku Ülikooli Toimetised = Ученые записки Тартуского университета = Acta et commentationes Universitatis Tartuensis 550. Tartu: [Tartu Riiklik Ülikool], lk 25-29.

Ariste, Paul 1990. Komi-Syrjänisches aus dem Dorfe Koni. Fennougristica 16 = Труды по финно-угроведению. Tartu Ülikooli Toimetised = Ученые записки Тартуского университета $=$ Acta et commentationes Universitatis Tartuensis 876. Tartu: [Tartu Ülikool], lk 156-163.

Komi rahvaluulet $2005=$ Komi rahvaluulet. Kogunud P. Ariste. Kuznetsov, Nikolai (koost.). Tartu: EKM folkloristika osakond. 